\title{
Parechovirus A Pathogenesis and the Enigma of Genotype A-3
}

\author{
Adithya Sridhar ${ }^{1, *,+} \mathbb{0}$, Eveliina Karelehto ${ }^{1, \dagger}{ }^{+}$Lieke Brouwer ${ }^{1}$, Dasja Pajkrt ${ }^{2} \mathbb{D}$ and \\ Katja C. Wolthers ${ }^{1}$ \\ 1 Laboratory of Clinical Virology, Department of Medical Microbiology, Amsterdam UMC, location Academic \\ Medical Center, University of Amsterdam, 1100 AZ Amsterdam, The Netherlands; \\ SuviEveliina.Karelehto@ucsf.edu (E.K.); lieke.brouwer@amsterdamumc.nl (L.B.); \\ k.c.wolthers@amsterdamumc.nl (K.C.W.) \\ 2 Department of Pediatrics, Emma Children's Hospital, Amsterdam UMC, location Academic Medical Center, \\ University of Amsterdam, 1100 AZ Amsterdam, The Netherlands; d.pajkrt@amsterdamumc.nl \\ * Correspondence: a.sridhar@amsterdamumc.nl \\ + These authors contributed equally to this work.
}

Received: 14 October 2019; Accepted: 12 November 2019; Published: 14 November 2019

\begin{abstract}
Parechovirus A is a species in the Parechovirus genus within the Picornaviridae family that can cause severe disease in children. Relatively little is known on Parechovirus A epidemiology and pathogenesis. This review aims to explore the Parechovirus $A$ literature and highlight the differences between Parechovirus $A$ genotypes from a pathogenesis standpoint. In particular, the curious case of Parechovirus-A3 and the genotype-specific disease association will be discussed. Finally, a brief outlook on Parechovirus A research is provided.
\end{abstract}

Keywords: parechovirus; parechovirus A; parechovirus A-3; pathogenesis

\section{Introduction}

Human parechoviruses, now officially known as Parechovirus A (PeV-A), are common childhood pathogens with a potential for severe clinical manifestations in infants [1,2]. Yet, the current understanding of PeV-A pathogenesis and epidemiology is remarkably limited. While PeV-A shares some similarities to enteroviruses (EVs), research on the biological and clinical aspects of PeV-A infection highlights differences between the genera. Within the PeV-A species, one of the most intriguing open questions is the genotype-specific disease association, i.e., why is severe illness almost exclusively caused by PeV-A3 and not by other genotypes? This review aims to look into this enigma and discuss what is currently known about the prevalence of PeV-A and pathogenesis.

\section{Genome and Structure}

The PeV-A virion is approximately $30 \mathrm{~nm}$ in diameter and is composed of a RNA genome shielded by an outer protein capsid lacking a lipid envelope [1,3]. The single-stranded positive-sense (+ss) genome is 7300 nucleotide (nt) long, contains a single open reading frame, and is flanked by untranslated regions (UTRs) [4]. The $700 \mathrm{nt}$ 5'UTR forms primary and secondary RNA structures that are crucial for replication and is attached to a viral protein called VPg [1,4]. An internal ribosomal entry site (IRES) within the $5^{\prime}$ UTR facilitates a direct cap-independent translation of a single large polyprotein which is cleaved into three structural proteins (VP0, VP3, and VP1) and seven non-structural proteins (2A-C and 3A-D) [4]. The $300 \mathrm{nt}$ 3'UTR terminates with a polyadenylated tail [4].

All picornavirus capsids adopt an icosahedral structure (see Figure 1) [5]. The three capsid proteins assemble into a protomer and five protomers together form a pentamer [5]. A total of 12 pentamers 
result in the final icosahedron defined by three axes of symmetry: (i) Two-fold axes along the edges of two protomers, (ii) three-fold axes along the protomer triangular faces, and (iii) five-fold axes along the pentamer vertices [6]. However, the atomic structures of PeV-A have revealed several features uncommon among other picornaviruses. The PeV-A capsid surface is relatively flat and misses the classic hydrophobic VP1 pocket (a target for small molecule capsid inhibitors blocking virus uncoating) as is seen in EVs [6,7]. The PeV-A VP0 capsid protein is not cleaved into VP2 and VP4 in the mature virion [4,6]. Furthermore, RNA packaging signals appear to guide the PeV-A capsid assembly [8,9]. Interestingly, procapsids (empty particles devoid of the RNA genome), as seen in many other picornaviruses, are not observed for PeV-A [6,10].

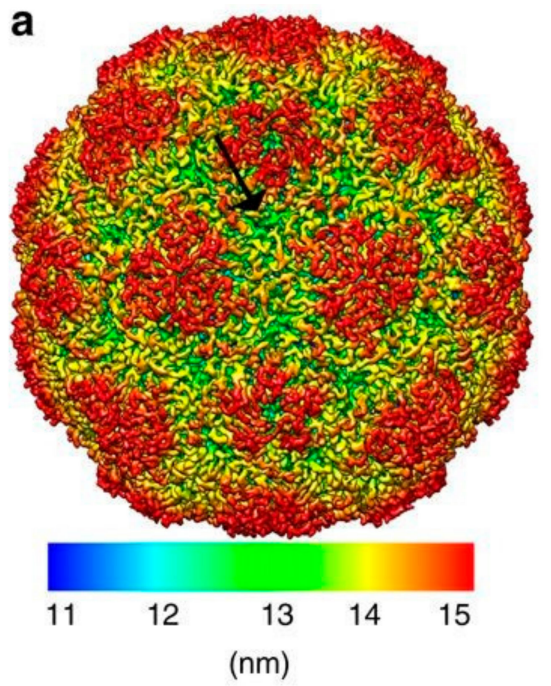

b

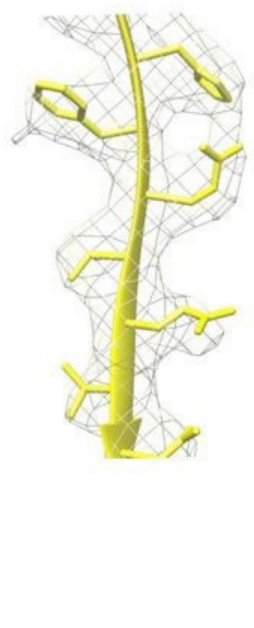

C

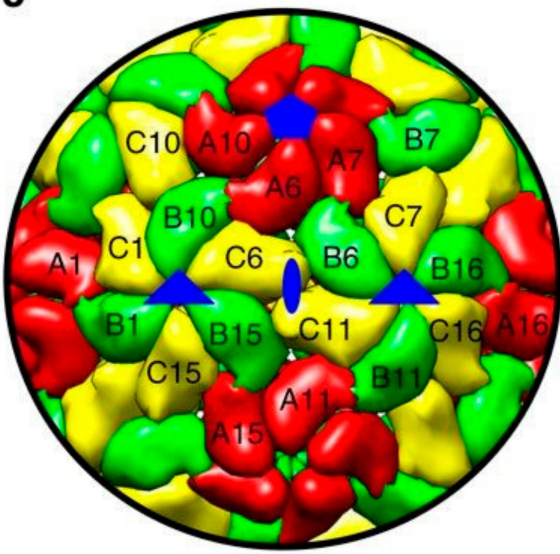

Figure 1. (a) Twofold axis of symmetry of PeV-A3 (Parechovirus A) at $4.3 \AA$ resolution, canyon indicated by the arrow, (b) representative fit of the VP0 atomic model, and (c) capsid model showing positions of VP0 (yellow), VP1 (red), and VP3 (green). In blue are the symmetry axes-fivefold pentagon, threefold triangle, and twofold ellipse. Image used under the terms of the Creative Commons Attribution License (CC BY 4.0.) from Shakeel, S. et al., 2016 [6].

\section{Classification}

Parechovirus is a genus within the family Picornaviridae, comprising of small non-enveloped, single-stranded positive-sense RNA viruses [11,12]. The genus is comprised of four species, Parechovirus A, Parechovirus B (formerly named Ljungan virus), Parechovirus C (Sebokele virus), and Parechovirus $D$ (ferret parechovirus) [13]. Species PeV-A contains virus genotypes that can infect humans and cause severe disease such as meningoencephalitis, seizures, or sepsis-like illness (see Section 6.1. for more information) [14,15]. PeV-A was first isolated as two unidentified viruses in 1956 in the USA from children with diarrhea [16]. They were initially classified as EVs, echovirus 22 and 23, based on their similarity in cytopathogenic effect (CPE), their clinical presentation, and non-pathogenicity in mice and monkeys [16]. In 1999, echovirus 22 and 23 were reclassified as PeV-A1 and PeV-A2, respectively, due to differences in genomic structures, encoded proteins, and other biological properties [4,17-19]. In 2004, genotype PeV-A3 was discovered in Japan followed by the discovery of PeV-A4 in the Netherlands in 2006 [20]. Since then the number of PeV-A types increased rapidly with the development of more state-of-the-art molecular techniques. Currently, there are 19 PeV-A types known with PeV-A1 divided into clusters 1A and 1B (Table 1) [21]. 
Table 1. (Left) Select list of PeV-A prototype strains (http://www.picornastudygroup.com/) [13]. Full list of prototype strains available on the picorna study group website.

\begin{tabular}{cccc}
\hline Type & Strain & Reference & Accession \\
\hline PeV-A1A & Harris & Hyypia et al., 1992 [22] & L02971 \\
PeV-A1B & BNI-788 St & Baumgarte et al., 2008 [23] & EF051629 \\
PeV-A2 & Williamson & Ghazi et al., 1998 [24] & AJ005695 \\
PeV-A3 & A308/99 & Ito et al., 2004 [25] & AB084913 \\
PeV-A4 & K251176-02 & Benschop et al., 2006b [20] & DQ315670 \\
PeV-A5 & CT86-6760 & Oberste et al., 1998 [17] & AF055846 \\
PeV-A6 & NII561-2000 & Watanabe et al., 2007 [26] & AB252582 \\
PeV-A7 & PAK5045 & Li et al., 2009 [27] & EU556224 \\
PeV-A8 & BR/217/2006 & Drexler et al., 2009 [28] & EU716175 \\
PeV-A9 & BAN2004-10902 & Nix et al., 2013 [29] & JX219575 \\
PeV-A10 & BAN2004-10903 & Nix et al., 2013 [29] & JX219568 \\
PeV-A11 & BAN2004-10905 & Nix et al., 2013 [29] & JX219574 \\
PeV-A12 & BAN2004-10904 & Nix et al., 2013 [29] & JX219567 \\
PeV-A13 & BAN2004-10901 & Nix et al., 2013 [29] & JX219579 \\
PeV-A14 & 451564 & Benschop et al., 2008c [30] & FJ373179 \\
PeV-A15 & BAN-11614 & Nix et al., 2013 [29] & JX219573 \\
PeV-A16 & BAN-11615 & Nix et al., 2013 [29] & JX219580 \\
PeV-A17 & M36/CI/2014 & Böttcher et al., 2017 [31] & KT319121 \\
PeV-A18 & GhanaA36 886 & Graul et al., 2017 [32] & KY931660 \\
PeV-A19 & P02-4058 & Brouwer et al., 2019 [33] & MH339678 \\
\hline
\end{tabular}

\section{Evolution}

The PeV-A lineage diverged from its most recent common ancestor around the year $1600 \mathrm{CE}$, while individual types might have diverged as recently as 150 years ago [34]. As with other picornaviruses, the RNA polymerase of $\mathrm{PeV}-\mathrm{A}$ lacks proofreading activity and $\mathrm{PeV}-\mathrm{As}$ have a high mutation rate of approximately $2.5 \times 10^{-3}$ [34]. In addition to this high mutation rate, recombination plays an important part of PeV-A evolution. Recombination has been shown to occur frequently between PeV-A1, A4, A5, and A6, with breakpoints mainly located at both ends of the structural VP1 region, and at the VP2/VP3 junction region $[21,35,36]$. Recombinant strains with a breakpoint located within the VP1 region are rare $[21,35,36]$. This is in accordance with the localization of recombination hotspots in other picornaviruses, such as enteroviruses [37].

The location of recombination breakpoints seems to correlate to the genetic diversity in the PeV-A genome, both the nt and amino acid variability are higher in the structural region than in the non-structural region [35]. This illustrates antigenic pressure on the structural region, while purifying selection is dominant in the non-structural region. Recombination might play an important role in establishing this as it would allow for mutations in the structural regions, while detrimental mutations in the non-structural region can be bypassed by adopting a non-structural genome segment from another PeV-A strain.

\section{Epidemiology}

There are clear indications that PeV-A circulates worldwide as it was detected in approximately $2 \%$ of specimens collected from children with a clinical suspicion of viral infections or as part of the national EV surveillance programs in Japan, Hong Kong, Denmark, Finland, the Netherlands, and the USA [14,15,38-43]. Furthermore, a remarkably high prevalence (23-57\%) was recently demonstrated for PeV-A in children from Malawi $[33,44]$.

Specific PeV-A genotypic prevalence varies globally. In Europe and the USA, PeV-A1 is most prevalent followed by PeV-A3 and PeV-A4, while PeV-A2, and A7-A19 are rarely reported [38,40-42,45,46]. In Asia, similar to Europe and the USA, PeV-A1, A3, and A4 are the most prevalent but a higher diversity of genotypes has been reported in India and Pakistan [47-49]. In the African continent, PeV-A1, A2, 
and $\mathrm{A} 3$ are the most prevalent but nearly all $\mathrm{PeV}$ genotypes are detected, indicating a much wider circulation of genotypes. Different genotype distributions have further been reported, for example in Pakistan and Ghana, underlining differences in prevalence and diversity between continents [32,50]. These genetic variations arise from not only error-prone RNA-dependent RNA polymerase, but also from recombination (see section on evolution for further details) [35,51]. The frequency of recombination was higher among PeV-A1 and PeV-A4 to A6 sequences as compared to PeV-A3 isolates [35,36]. However, a recent outbreak of neonatal sepsis in Australia was caused by a recombinant PeV-A3 strain [52].

PeV-A infection also shows a clear seasonality with a majority of infections recorded in late summer and fall [53-55]. Interestingly, PeV-A3, in contrast to the other genotypes, has been reported to circulate biannually in the Netherlands and Scotland [41,56]. Ultimately, epidemiological studies reporting PeV-A prevalence vary greatly between cohorts in age, clinical presentation, and sample types collected, hampering direct comparisons. Increases in sequencing efforts and standardization of diagnostic PeV-A testing will lead to improved insights on both PeV-A epidemiology and diversity.

In parallel, seroepidemiological studies determine the prevalence of neutralizing antibodies (nAbs) against a specific pathogen in sera of a defined population. Such studies provide a good estimate of virus prevalence, the potential immune status of different patient groups, and circulation in humans. Seropositivity of PeV-A1 nAbs sharply increases in children aged two to five years and is nearly universal in adults based on reports from Finland, the Netherlands, and Japan [57-61]. This is in line with clinical studies showing PeV-A1 as the most common genotype with infections occurring primarily in young children [1]. The seroprevalence of PeV-A2 and PeV-A4 to A6 nAbs is relatively high in Finland, the Netherlands, and Japan [59,61]. Recently, a high overall seroprevalence (68.9\%) of PeV-A3 among Dutch, the USA, and Australian populations was shown, which is suggestive of widespread global circulation. Our age-stratified analyses indicated that the infection generally occurs in children younger than 10 years. However, since cross-neutralization among the genotypes PeV-A1/A2 and $\mathrm{PeV}-\mathrm{A} 4$ to $\mathrm{A} 6$ has been observed, unequivocal conclusions about the epidemiology of these genotypes are difficult to base on this data alone [62,63].

\section{Life Cycle}

The PeV-A life cycle after entry is assumed to be similar to other picornaviruses (for review see $[64,65]$ ) but experimental evidence is lacking. Briefly, once the virus binds to the host cell surface receptor, endocytosis is initiated. This is followed by uncoating and RNA genome release into the cytoplasm. Then the viral RNA is translated by the host ribosomes into the polyprotein precursor. Subsequently, an extensive remodeling of the intracellular membranes is induced. This results in the formation of either single- or bilayer lipid vesicles termed replication organelles, where replication occurs [66-68]. The new RNA can serve as a template for further rounds of replications or be translated in a cap-independent manner into a single large polyprotein. This polyprotein is cleaved into structural and non-structural proteins. Unlike many other picornaviruses, the PeV-A VP0 capsid protein is not cleaved into VP2 and VP4, in the mature virion [4,6]. Another unique feature for PeV-A is that the non-structural $2 \mathrm{~A}$ protein does not possess proteolytic activity and induce host translation shut-off $[19,69]$. At the end of the replication cycle, the RNA is encapsidated by the structural proteins to form new infectious particles. The final stage of the PeV-A life cycle is the release from the host cell.

Release can occur through different mechanisms in picornaviruses. Non-enveloped viruses have been traditionally thought to be released via cell lysis. However, several independent reports now point toward an alternative non-lytic egress mechanism. Hepatitis A virus, poliovirus, EV-A71, and coxsackievirus B3 (CV-B3) have all been reported to exit infected cells within host cell derived vesicle structures [70-74]. The proposed mechanism involves hijacking autophagy pathway components to induce the formation of double-membrane vesicles, capable of fusing with the plasma membrane for exit $[71,74]$. These virus-containing extracellular microvesicles are speculated to facilitate virus 
dissemination and immune evasion [70,71]. PeV-A is known to release via cell lysis as CPE can be observed in vitro but whether the non-lytic mechanisms are also involved remains to be seen.

\section{Receptors}

For most PeV-A genotypes, the receptors involved in viral binding and entry have not been identified and it remains to be seen if there is a universal PeV-A receptor. Presently, nt divergence in the receptor binding capsid VP1-encoding sequence is used to subgroup PeV-A into the 19 detected genotypes $[11,17,20]$. Some of these genotypes contain an integrin-binding tripeptide arginine-glycine-aspartic acid (RGD) motif in the VP1 C terminus [1,3]. 8 of the 24 known integrin (ITG) heterodimer combinations can bind cellular ligands via the RGD motif [75]. Not surprisingly, other picornaviruses such as echoviruses 1 and 9, and coxsackievirus A9 (CV-A9) have this motif and have been shown to use ITGs as receptors [18,76-78].

The structural modeling of PeV-A1 indicates that the RGD motif is located between the icosahedral five-fold and three-fold axes on the capsid surface [6,7]. The deletion of the RGD motif results in the loss of PeV-A1 infectivity [79]. Therefore, several groups have investigated the role of $\alpha \mathrm{v}$ ITG heterodimers in PeV-A1 infection. Based on a phage display screening, it was suggested that PeV-A1 preferentially uses $\alpha \mathrm{v} \beta 1$ ITG as a receptor [18]. Experiments employing integrin-blocking monoclonal antibodies (mAbs) indicated $\alpha \mathrm{v} \beta 3$ ITG as the primary PeV-A1 receptor [80]. One report confirmed that both $\alpha \mathrm{v} \beta 3$ and $\alpha \mathrm{v} \beta 1$ integrin heterodimers were involved in PeV-A1 infection while others describe $\alpha v \beta 6$ ITG as the high affinity receptor for PeV-A1 [81]. More recently, it was reported that PeV-A1 infection occurs via $\alpha \mathrm{V} \beta 1$ ITG [82]. Taken together, these results indicate that integrins facilitate PeV-A1 infection but the use of specific heterodimers may be cell line dependent. While ITGs are important for virus binding and entry in cell lines, ITGs may not be exclusive receptors in vivo. In studies on human airway epithelial (HAE) cultures, we found no effect of $\alpha v$ ITG blocking on PeV-A1 and PeV-A3 infection [83]. Interestingly, PeV-A1 strains lacking VP1 C-terminal RGD sequence have been isolated from a Dutch child [84]. Furthermore, PeV-A3 and PeV-A7 to A19 lack the RGD motif and ITGs are assumed not to be involved in entry $[1,25]$. However, the lack of the RGD motif does not preclude ITG binding and integrin-ligand interactions can occur in a RGD-independent manner. For example, the very late antigen 2 (also known as $\alpha 2 \beta 1$ ITG) has been shown to mediate echovirus 1 infection in this way $[77,85,86]$.

The presence of a RGD sequence does not exclude the involvement of other entry receptors and ITG independent infection has been described in RGD motif containing viruses such as CV-A9 [87]. We showed that heparin sulfate (HS) is involved in PeV-A1 infection in the human lung adenocarcinoma A549 cell line [88]. However, we could not confirm the role of HS in the HAE model [83]. In this model, we also observed that both PeV-A1 (with RGD in VP1) and PeV-A3 (RGD-less) preferentially infect basal cells from the basolateral surface (see Figure 2) [83]. Either, these closely related viruses are utilizing separate receptors to gain entry into the same cell type or perhaps they share a yet unidentified receptor. If it is the latter, then one interesting possibility is beta-2-microglobulin $(\beta 2 \mathrm{M})$, a component of the antigen-presenting major histocompatibility complex I (MHC 1) [89,90]. Initially, $\beta 2 \mathrm{M}$ was shown not to be involved in the PeV-A1 infection of A549 and RD cell lines [79,80]. However, recent reports show $\beta 2 \mathrm{M}$ blocking significantly reduced PeV-A1 infection in the SW480 cell line and co-localization of $\beta 2 \mathrm{M}$ and PeV-A1 was observed in the A549 cell line [87].

As a side note, $\beta 2 \mathrm{M}$ binding draws interesting parallels to echoviruses, under which the PeV-A was initially classified. Some echoviruses such as echovirus 1 use $\alpha 2 \beta 1$ ITG as a primary receptor but this ITG is not a receptor for other echoviruses [77]. Recently, the neonatal Fc receptor (FcRn) was shown to be a pan-echovirus receptor [91]. FcRn has a binding partner in $\beta 2 \mathrm{M}$ and loss of $\beta 2 \mathrm{M}$ expression renders cells resistant to echovirus infection. Perhaps, through $\beta 2 \mathrm{M}, \mathrm{PeV}-\mathrm{A}$ share more than clinical similarities to echoviruses. 
In conclusion, the exact receptors used by PeV-A remains an open question but ITGs, HS, and $\beta 2 \mathrm{M}$ play a role in viral binding. The identification of receptors in physiologically relevant models for PeV-A will be a step forward in understanding parechovirus pathogenesis.

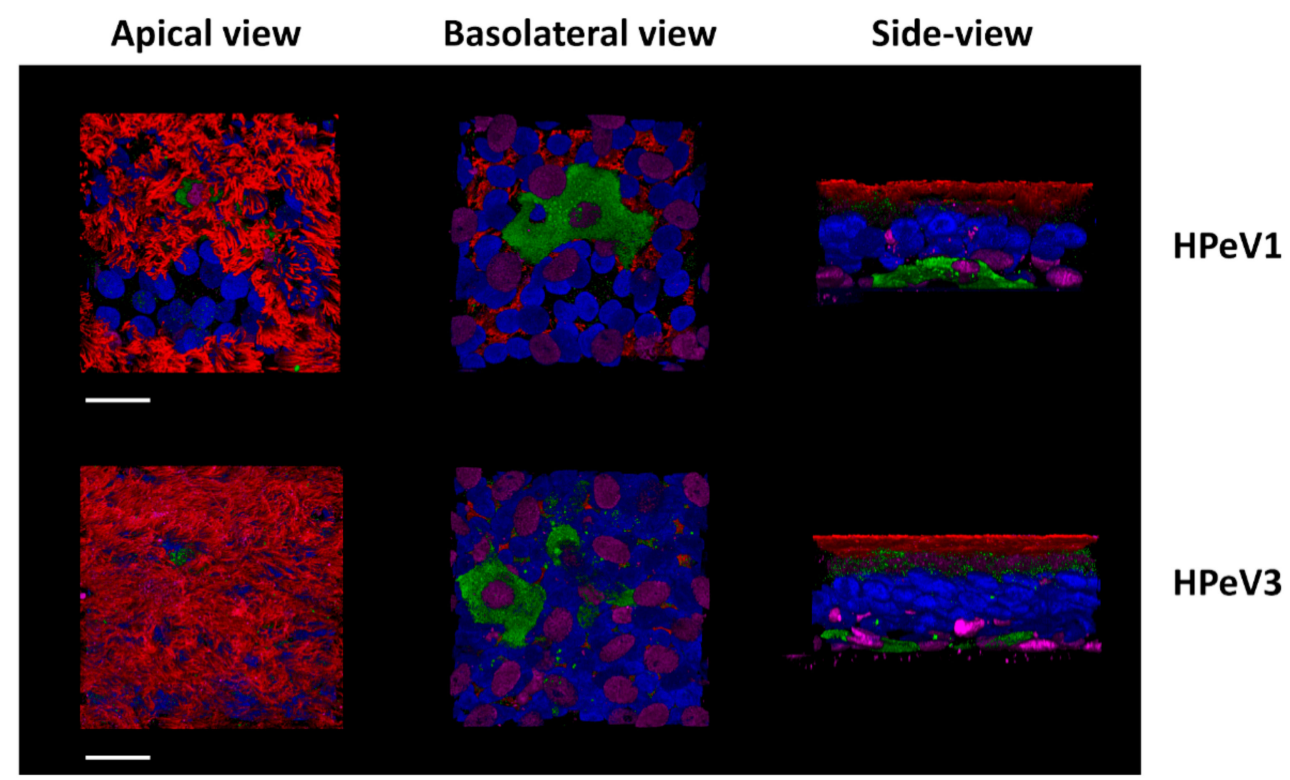

Figure 2. Immunofluorescence image of human airway epithelia (HAE) inserts infected with PeV-A1 and PeV-A3. Both genotypes appear to have a tropism for basal cells in the airway epithelium. Legend: Blue-DAPI (nuclei), Red- $\beta$-tub (ciliated cells), Green-PeV-A, and purple-p63 (basal cells). Image used under the terms of the Creative Commons Attribution License (CC BY 4.0.) from Karelehto E. et al., 2018 [83].

\section{Pathogenesis}

Due to the lack of suitable model systems, the current understanding of PeV-A pathogenesis is very limited. Thus, the primary replication site and initial cell tropism as well as target organs (secondary infection sites) are unknown. PeV-A infection is presumed to occur via fecal-oral and respiratory routes based on similarities to infection routes of EVs and PeV-A detection in stool and nasopharyngeal (NP) samples [92]. While there is no direct experimental evidence to support this hypothesis, transmission via the fecal-oral route is likely based on the prolonged stool shedding of this virus $[93,94]$.

\subsection{Clinical Manifestation and Detection}

Clinical manifestations following PeV-A infection range from asymptomatic or mild symptoms to severe disease. While a definitive association with symptomatology has not been established for many of the PeV-A genotypes, the causal relationship of PeV-A3 infections with a number of clinical conditions is evident [95]. PeV-A1 is associated with acute gastroenteritis, upper respiratory tract symptoms, fever, and rash in children between 6 months to 5 years [14,15,45]. In addition to these rather mild symptoms, PeV-A3 often causes severe disease in infants under the age of 3 months [1,3]. Several outbreaks of neonatal sepsis-like illness due to PeV-A3 infection have also been recorded, most recently in Australia [96-100]. Central nervous system (CNS) syndromes such as acute flaccid paralysis, meningitis, and encephalitis have been reported for PeV-A1 and A3 [2,4,25,101]. However, CNS complications are more commonly associated with PeV-A3 infection and in some instances, long-term neurodevelopmental sequelae have been reported [101-105]. It must be noted that these long-term neurological complications are rare and further studies are needed to formally assess long-term outcomes [106-108]. Epidemics of myalgia and a case of myocarditis in PeV-A3 infected adults have been reported but overall, PeV-A detection in adults is rare [1,109-112]. 
PeV-As can be detected in feces, NP swabs, blood, and cerebrospinal fluid (CSF) [1]. Most PeV-A epidemiological studies are performed using feces samples from children younger than 5 years of age, presenting with symptoms of acute gastroenteritis $[38,45,47,113,114]$. Furthermore, some published reports focus on children with respiratory or neurological symptoms with NP, CSF, and serum samples [2,115-119]. Diagnostic detection of PeV-A is performed by RT-qPCR targeting the untranslated region (UTR) of the $5^{\prime}$ end which is conserved among all PeV-A genotypes [92,120]. The PeV-A genotype is determined by the partial or complete sequencing of the VP- 1 encoding region but genotyping is not routinely performed [92]. PeV-A1-A6 can be detected by virus culture, but PeV-A3 needs different cell lines than the other PeVs and compared to molecular detection, this method is less sensitive [92].

\subsection{Immune Response}

Once the virus enters the body, the host immune responses are engaged to actively counter the viral infection. Unfortunately, the information on host immune responses against PeV-A is scarce. In general, the host innate and adaptive immune response appear to efficiently control the PeV-A spread as infections are largely self-resolving. Pattern recognition receptors, such as toll-like receptors (TLRs), melanoma differentiation-associated gene 5 , and retinoic acid-inducible gene I, form key host defense mechanisms against intracellular pathogens $[5,121]$. In case of PeV-A1, TLR7, and TLR8 are important in recognizing the single stranded RNA early in the infection [122]. This recognition subsequently activates the NF- $\kappa \beta$ signaling pathway and ultimately leads to the secretion of proinflammatory cytokines such as interferon $\beta$ (IFN- $\beta$ ), tumor necrosis factor a (TNF- $\alpha$ ), and interleukin 6 (IL-6). It has been shown that PeV-A1 infection induces the type 1 interferon response by phosphorylation of the upstream IFN regulatory factor 3 [123]. More recently, PeV-A1 was also shown to activate the signaling downstream of TLR3 [124]. How the PeV-A1 proteins modulate these pathways is not known. We investigated the genotypic differences in the innate immune response between PeV-A1 and PeV-A3 using an adult HAE model system. We observed that PeV-A3 induced a significantly stronger activation of genes involved in immune and inflammatory signaling [83]. This initial host response may dictate the viral spread and different clinical outcomes between PeV-A1 and PeV-A3.

The role of T-cell immunity in picornavirus infection is not well-defined. In a single study published on T-cell immunity against PeV-A infection, reactivity to the capsid proteins was observed in 20 adults by measuring T-cell proliferation upon exposure to recombinant VP0, VP3, and VP1 proteins [125]. Increased T-cell proliferation in response to PeV-A1 capsids indicate that T-cell immunity could play a role during PeV-A infection.

With respect to the antibody responses, although the administration of intravenous immunoglobulins (IVIG) in an immunodeficient adolescent with a chronic PeV-A1 infection did not reduce the PeV-A1 viral load [126], IVIG administration was associated with the full recovery of a PeV-A1 infection in a child presenting with severe dilated cardiomyopathy [127]. In animal studies, PeV-A1 VP1 C terminus has been shown to be immunogenic. Rabbits immunized with peptide antigen corresponding to the VP1 region elicited nAbs against PeV-A1 [57]. In terms of the neutralizing antibody responses, the RGD motif appears to play a role. A human monoclonal antibody epitope was mapped to the VP1 C-terminal RGD-region of PeV-A1 [128]. nAbs targeting the RGD motif cross neutralize other PeV-A genotypes (PeV-A2 and PeV-A4 to A6) that contain this motif [57,62]. Other immunodominant epitopes include the N-terminal region of the PeV-A1 VP0 capsid encoding region and VP0/VP3 loops on the capsid surface [128].

During the first 3 to 6 months of life, maternal nAbs protect neonates against infection. While maternal nAbs protect against disease related to most PeV-A genotypes, $\mathrm{PeV}-\mathrm{A} 3$ is again an exception. Severely ill neonates lacked maternal nAbs against PeV-A3 at the onset of a disease and mothers from neonates with PeV-A3 infections showed no or low a-PeV-A3 Ab titers [129,130]. 


\section{PeV-A3 Stands Out Amongst the PeV-A Genotypes}

Although the review has focused on the PeV-A species as a whole, special attention is warranted for PeV-A3 which is repeatedly observed as an exception amongst the PeV-A genotypes. For instance, the lack of a RGD motif and biannual circulation of PeV-A3 in comparison to other PeV-A genotypes are interesting. Furthermore, $\mathrm{PeV}-\mathrm{A} 3$ rarely recombines with any of the other types but recombination does occur within the genotype [131]. The most striking feature of PeV-A3 infection is the severity in its clinical manifestation. The reason behind the severe clinical presentation of $\mathrm{PeV}-\mathrm{A} 3$ as opposed to the more prevalent PeV-A1 remains a critical question. The clinical differences in PeV-A1 vs PeV-A3 could perhaps be linked to the immune response to these genotypes.

\section{Host Responses Gone Astray?}

Both the innate and adaptive immune responses have been shown to be different for PeV-A3 as compared to the other PeV-As. Our group showed on HAE cultures, PeV-A3 induced a much stronger activation of genes involved in immune and inflammatory signaling [83]. In neonates with an immature or still developing immune system, this strong activation could result in severe immunopathology. This is supported by the fact that elevated levels of proinflammatory cytokines and systemic inflammatory response have been linked to the severe pathogenesis of EV-A71 [132-134] while the concept of cytokine storm is well established for respiratory pathogens such as influenza virus and human coronavirus $[135,136]$.

Neonatal sepsis, also known as systemic inflammatory response syndrome, is the most common severe clinical manifestation of $\mathrm{PeV}-\mathrm{A} 3$ and points towards immunopathology during the PeV-A3 infection of neonates. Neonatal sepsis is associated with the increased vascular permeability and reduced blood-brain barrier (BBB) function. Viremia and increased BBB permeability resulting from neonatal sepsis during PeV-A3 infection may allow passive virus leakage into the CNS [137-140]. Thus, detection of PeV-A3 RNA in the CSF samples of severely ill infants may not be a sign of active virus replication in the CNS but rather a consequence of a systemic inflammatory response. This is supported by several studies reporting that PeV-A3 positive CSF samples often do not show increase in white blood cell count $[96,141-145]$. However, as a counter to this, our group has shown that $\mathrm{PeV}-\mathrm{A} 3$ is capable of infecting neuronal cell lines and PeV-A3 isolates replicated human neuroblastoma cell lines more efficiently than PeV-A1, suggesting a neural tropism of PeV-A3 [146]. Therefore, viral replication in the CNS could potentially lead to encephalitis, meningitis, and adverse long-term neurodevelopmental outcomes that is seen in pediatric PeV-A3 infection.

Another reason for exacerbated disease in neonates upon PeV-A3 infection might be related to humoral immunity. We and others have shown the titers of PeV-A3 nAbs are below the expected levels of protection in adults over 30 years $[61,130,147]$. This is further supported by the lack of neutralization of PeV-A3 in a small serosurvey of adults from Wisconsin, USA [148]. This is different from PeV-A1 where the $\mathrm{nAb}$ levels are maintained in adults. No cross protection from PeV-A1 antibodies is expected for PeV-A3 and it has been shown that hyperimmune serum raised in rabbits against PeV-A1 did not cross-neutralize PeV-A3 [62]. Thus, low nAb titers in women of childbearing age may lead to inadequate maternal antibody protection contributing to PeV-A3 outbreaks in infants. Hence, we speculate that the severe PeV-A3 presentation in young infants is due to both insufficient (adaptive) and excessive (innate) host immune responses.

\section{Treatment}

Currently, there are no specific antiviral therapies clinically available against PeV-A infection. Treatment options are limited to supportive care and occasionally passive immunization by the administration of IVIG [3]. The development of targeted antiviral drugs requires detailed knowledge of the virus lifecycle but this is poorly defined [149]. Few studies have screened EV inhibitors against PeV-A but these have indicated that the capsid morphology, protease functions, and host factor 
dependency differ between these two genera [149]. For instance, pleconaril (an EV capsid inhibitor) was unable to inhibit PeV-A replication due to differences in the capsid structures, whereby large amino acid side chains block the hydrophobic drug binding site on the surface of PeV-A $[6,7,126]$. Similarly, EV 3C protease, EV 2C inhibitors, and golgi transport inhibitor (Brefeldin A, effective against EV) failed to inhibit PeV-A1 replication [68,150,151]. Another host factor-targeting compound, the antifungal agent Itraconazole (ITZ), was shown to have antiviral activity against PeV-A3 but not against PeV-A1 [152]. ITZ is highly interesting as it is a FDA-approved drug and has a favorable safety profile in pediatric patients. Thus, ITZ looks promising for PeV-A3 treatment but further research into the pathogenesis of $\mathrm{PeV}-\mathrm{A}$ is needed to design targeted antiviral therapies.

Given that maternal nAbs appear to be protective against severe disease related to PeV-A infection, the development of therapeutic mAbs is an unmet clinical need [62]. We have isolated and characterized the structure and function of human PeV-A mAbs in detail and found that several of them neutralize PeV-A1 and other RGD-containing genotypes efficiently [128]. One of the mAbs is capable of neutralizing PeV-A3 but unfortunately only the antigenically distinct prototype strain and not the circulating clinical strains $[6,153,154]$. Nevertheless, these data represent a promising step towards antibody treatment of PeV-A infections.

\section{Outlook}

In this review, we discussed the epidemiology of PeV-A and summarized the current understanding in PeV-A pathogenesis. However, information on the prevalence and pathogenesis of PeV-A is limited. PeV-A studies have relied on the use of immortalized cell lines that, while useful, are still poor models for pathogenesis studies. Animal models expressing virus-specific human receptors have been the gold standard in picornavirus research but no such model exists for PeV-A infection. Newborn mice and cynomolgus monkeys have been experimentally infected with PeV-A1 and newborn mice with PeV-A3 but with no apparent pathologies associated [16,25]. In order to elucidate entry and pathogenesis, the identification of a PeV-A receptor is critical and may lead to the generation of a transgenic animal model.

Alternatively, the use of complex organotypic human cell culture models could be a way forward in understanding PeV-A pathogenesis. One such model is the well-differentiated HAE cell culture system in which primary human epithelial cells from airway tissue are cultured on transwell inserts. Our group used this model for studying PeV-A infection and identified basal cells as the cell type that PeV-A1 and A3 infect in the airway. A recent breakthrough in similarly culturing the gut epithelium using stem cells from intestinal crypts could also be used for studying PeV-A [155]. These primary culture systems, termed organoids, have been developed for various organs including the brain [156]. They recapitulate the cell composition, organization, and tissue microenvironment in vitro and will be valuable for understanding pathogenesis in the human setting.

Another important reason to expand our understanding of PeV-A pathogenesis is to address the lack of therapeutic options. Currently, there is no rationale for vaccine development but efforts such as the antigenic profiling of PeV-A genotypes is crucial and may lead to the discovery of therapeutic monoclonal antibodies. Alternatively, knowledge of the PeV-A replication cycle could result in the development of targeted antiviral compounds.

Perhaps, one of the most intriguing open question in PeV-A biology is the genotype specific disease association. Why is severe illness almost exclusively caused by PeV-A3 and not by other genotypes? We have hypothesized based on experimental findings in HAE models and observed humoral response that this could be due to the immune response against PeV-A3 infection. Further experiments are needed to assess whether this is indeed the case. Future research in this area should also aim to characterize the molecular and cellular determinants of PeV-A immune modulation across various tissues in both infants and adults.

In conclusion, $\mathrm{PeV}-\mathrm{A}$ are common childhood pathogens with a potential for severe clinical disease in infants. While current knowledge is limited, it presents a unique opportunity for picornavirologists 
to explore a clinically relevant pathogen. We anticipate that identification of a receptor and use of organotypic models will drive the PeV-A research field forward in the coming years.

Funding: This study was funded by the ZonMW's Meer Kennis met Minder Dieren grant (114021506).

Conflicts of Interest: The authors declare no conflict of interest.

$\begin{array}{ll}\text { Abbreviations } \\ \text { PeV-A } & \text { Parechovirus A } \\ \text { EV } & \text { Enterovirus } \\ \text { nt } & \text { Nucleotide } \\ \text { UTR } & \text { Untranslated region } \\ \text { CPE } & \text { Cytopathogenic effect } \\ \text { nAbs } & \text { Neutralizing antibodies } \\ \text { CV } & \text { Coxsackievirus } \\ \text { RGD } & \text { Arginine-glycine-aspartic acid } \\ \text { ITG } & \text { Integrin } \\ \text { mAbs } & \text { Monoclonal antibodies } \\ \text { HAE } & \text { Human Airway Epithelial } \\ \text { HS } & \text { Heparin Sulfate } \\ \beta 2 M & \text { beta-2-microglobulin } \\ \text { FcRn } & \text { Neonatal Fc receptor } \\ \text { NP } & \text { nasopharyngeal } \\ \text { CNS } & \text { Central nervous system } \\ \text { CSF } & \text { Cerebrospinal fluid } \\ \text { TLR } & \text { Toll-like receptor } \\ \text { IFN } & \text { Interferon } \\ \text { IVIG } & \text { Intravenous immunoglobulin } \\ \text { BBB } & \text { Blood-brain barrier } \\ \text { ITZ } & \text { Itraconazole }\end{array}$

\section{References}

1. Romero, J.R.; Selvarangan, R. The human Parechoviruses: An overview. Adv. Pediatr. 2011, 58, 65-85. [CrossRef]

2. Wolthers, K.C.; Benschop, K.S.; Schinkel, J.; Molenkamp, R.; Bergevoet, R.M.; Spijkerman, I.J.; Kraakman, H.C.; Pajkrt, D. Human parechoviruses as an important viral cause of sepsislike illness and meningitis in young children. Clin. Infect. Dis. 2008, 47, 358-363. [CrossRef]

3. Wildenbeest, J.G.; Harvala, H.; Pajkrt, D.; Wolthers, K.C. The need for treatment against human parechoviruses: How, why and when? Expert Rev. Anti Infect. Ther. 2010, 8, 1417-1429. [CrossRef]

4. Stanway, G.; Kalkkinen, N.; Roivainen, M.; Ghazi, F.; Khan, M.; Smyth, M.; Meurman, O.; Hyypia, T. Molecular and biological characteristics of echovirus 22, a representative of a new picornavirus group. J. Virol. 1994, 68, 8232-8238.

5. $\quad$ Feng, Q.; Hato, S.V.; Langereis, M.A.; Zoll, J.; Virgen-Slane, R.; Peisley, A.; Hur, S.; Semler, B.L.; van Rij, R.P.; van Kuppeveld, F.J. MDA5 detects the double-stranded RNA replicative form in picornavirus-infected cells. Cell Rep. 2012, 2, 1187-1196. [CrossRef] [PubMed]

6. Shakeel, S.; Westerhuis, B.M.; Domanska, A.; Koning, R.I.; Matadeen, R.; Koster, A.J.; Bakker, A.Q.; Beaumont, T.; Wolthers, K.C.; Butcher, S.J. Multiple capsid-stabilizing interactions revealed in a high-resolution structure of an emerging picornavirus causing neonatal sepsis. Nat. Commun. 2016, 7, 11387. [CrossRef] [PubMed]

7. Kalynych, S.; Palkova, L.; Plevka, P. The Structure of Human Parechovirus 1 Reveals an Association of the RNA Genome with the Capsid. J. Virol. 2016, 90, 1377-1386. [CrossRef] [PubMed] 
8. Shakeel, S.; Evans, J.D.; Hazelbaker, M.; Kao, C.C.; Vaughan, R.C.; Butcher, S.J. Intrinsically-disordered N-termini in human parechovirus 1 capsid proteins bind encapsidated RNA. Sci. Rep. 2018, 8, 5820. [CrossRef]

9. Shakeel, S.; Dykeman, E.C.; White, S.J.; Ora, A.; Cockburn, J.J.B.; Butcher, S.J.; Stockley, P.G.; Twarock, R. Genomic RNA folding mediates assembly of human parechovirus. Nat. Commun. 2017, 8, 5. [CrossRef]

10. Fernandez-Tomas, C.B.; Guttman, N.; Baltimore, D. Morphogenesis of poliovirus 3. Formation of provirion in cell-free extracts. J. Virol. 1973, 12, 1181-1183.

11. Zell, R.; Delwart, E.; Gorbalenya, A.E.; Hovi, T.; King, A.M.Q.; Knowles, N.J.; Lindberg, A.M.; Pallansch, M.A.; Palmenberg, A.C.; Reuter, G.; et al. ICTV Virus Taxonomy Profile: Picornaviridae. J. Gen. Virol. 2017, 98 , 2421-2422. [CrossRef] [PubMed]

12. Adams, M.J.; Lefkowitz, E.J.; King, A.M.; Harrach, B.; Harrison, R.L.; Knowles, N.J.; Kropinski, A.M.; Krupovic, M.; Kuhn, J.H.; Mushegian, A.R.; et al. Ratificatio n vote on taxonomic proposals to the International Committee on Taxonomy of Viruses. Arch. Virol. 2016, 161, 2921-2949. [CrossRef] [PubMed]

13. Parechovirus. Available online: http://www.picornaviridae.com/parechovirus/parechovirus.htm (accessed on 10 October 2019).

14. Ito, M.; Yamashita, T.; Tsuzuki, H.; Kabashima, Y.; Hasegawa, A.; Nagaya, S.; Kawaguchi, M.; Kobayashi, S.; Fujiura, A.; Sakae, K.; et al. Detection of human parechoviruses from clinical stool samples in Aichi, Japan. J. Clin. Microbiol. 2010, 48, 2683-2688. [CrossRef] [PubMed]

15. Chiang, G.P.K.; Chen, Z.; Chan, M.C.W.; Lee, S.H.M.; Kwok, A.K.; Yeung, A.C.M.; Nelson, E.A.S.; Hon, K.L.; Leung, T.F.; Chan, P.K.S. Clinical features and seasonality of parechovirus infection in an Asian subtropical city, Hong Kong. PLoS ONE 2017, 12, e0184533. [CrossRef] [PubMed]

16. Wigand, R.; Sabin, A.B. Properties of ECHO types 22, 23 and 24 viruses. Arch. Gesamte Virusforsch 1961, 11, 224-247. [CrossRef] [PubMed]

17. Oberste, M.S.; Maher, K.; Pallansch, M.A. Complete sequence of echovirus 23 and its relationship to echovirus 22 and other human enteroviruses. Virus Res. 1998, 56, 217-223. [CrossRef]

18. Pulli, T.; Koivunen, E.; Hyypia, T. Cell-surface interactions of echovirus 22. J. Biol. Chem. 1997, 272, 21176-21180. [CrossRef]

19. Coller, B.A.; Chapman, N.M.; Beck, M.A.; Pallansch, M.A.; Gauntt, C.J.; Tracy, S.M. Echovirus 22 is an atypical enterovirus. J. Virol. 1990, 64, 2692-2701.

20. Benschop, K.S.; Schinkel, J.; Luken, M.E.; van den Broek, P.J.; Beersma, M.F.; Menelik, N.; van Eijk, H.W.; Zaaijer, H.L.; VandenBroucke-Grauls, C.M.; Beld, M.G.; et al. Fourth human parechovirus serotype. Emerg. Infect. Dis. 2006, 12, 1572-1575. [CrossRef]

21. Williams, C.H.; Panayiotou, M.; Girling, G.D.; Peard, C.I.; Oikarinen, S.; Hyoty, H.; Stanway, G. Evolution and conservation in human parechovirus genomes. J. Gen. Virol. 2009, 90, 1702-1712. [CrossRef]

22. Hyypia, T.; Horsnell, C.; Maaronen, M.; Khan, M.; Kalkkinen, N.; Auvinen, P.; Kinnunen, L.; Stanway, G. A distinct picornavirus group identified by sequence analysis. Proc. Natl. Acad. Sci. USA 1992, 89, 8847-8851. [CrossRef] [PubMed]

23. De Souza Luna, L.K.; Baumgarte, S.; Grywna, K.; Panning, M.; Drexler, J.F.; Drosten, C. Identification of a contemporary human parechovirus type 1 by VIDISCA and characterisation of its full genome. Virol. J. 2008, 5, 26. [CrossRef] [PubMed]

24. Ghazi, F.; Hughes, P.J.; Hyypia, T.; Stanway, G. Molecular analysis of human parechovirus type 2 (formerly echovirus 23). J. Gen. Virol. 1998, 79 Pt 11, 2641-2650. [CrossRef]

25. Ito, M.; Yamashita, T.; Tsuzuki, H.; Takeda, N.; Sakae, K. Isolation and identification of a novel human parechovirus. J. Gen. Virol. 2004, 85, 391-398. [CrossRef] [PubMed]

26. Watanabe, K.; Oie, M.; Higuchi, M.; Nishikawa, M.; Fujii, M. Isolation and characterization of novel human parechovirus from clinical samples. Emerg. Infect. Dis. 2007, 13, 889-895. [CrossRef] [PubMed]

27. Li, L.; Victoria, J.; Kapoor, A.; Naeem, A.; Shaukat, S.; Sharif, S.; Alam, M.M.; Angez, M.; Zaidi, S.Z.; Delwart, E. Genomic characterization of novel human parechovirus type. Emerg. Infect. Dis. 2009, 15, 288-291. [CrossRef]

28. Drexler, J.F.; Grywna, K.; Stocker, A.; Almeida, P.S.; Medrado-Ribeiro, T.C.; Eschbach-Bludau, M.; Petersen, N.; da Costa-Ribeiro, H., Jr.; Drosten, C. Novel human parechovirus from Brazil. Emerg. Infect. Dis. 2009, 15, 310-313. [CrossRef] 
29. Nix, W.A.; Khetsuriani, N.; Penaranda, S.; Maher, K.; Venczel, L.; Cselko, Z.; Freire, M.C.; Cisterna, D.; Lema, C.L.; Rosales, P.; et al. Diversity of picornaviruses in rural Bolivia. J. Gen. Virol. 2013, 94, 2017-2028. [CrossRef]

30. Benschop, K.; Thomas, X.; Serpenti, C.; Molenkamp, R.; Wolthers, K. High prevalence of human Parechovirus $(\mathrm{HPeV})$ genotypes in the Amsterdam region and identification of specific $\mathrm{HPeV}$ variants by direct genotyping of stool samples. J. Clin. Microbiol. 2008, 46, 3965-3970. [CrossRef]

31. Bottcher, S.; Obermeier, P.E.; Diedrich, S.; Kabore, Y.; D’Alfonso, R.; Pfister, H.; Kaiser, R.; Di Cristanziano, V. Genome Sequence of Novel Human Parechovirus Type 17. Genome Announc. 2017, 5. [CrossRef]

32. Graul, S.; Bottcher, S.; Eibach, D.; Krumkamp, R.; Kasmaier, J.; Adu-Sarkodie, Y.; May, J.; Tannich, E.; Panning, M. High diversity of human parechovirus including novel types in stool samples from Ghanaian children. J. Clin. Virol. 2017, 96, 116-119. [CrossRef] [PubMed]

33. Brouwer, L.; Karelehto, E.; Han, A.X.; Thomas, X.V.; Bruning, A.H.L.; Calis, J.C.J.; van Hensbroek, M.B.; Westerhuis, B.M.; Amarthalingam, D.; Koekkoek, S.M.; et al. High frequency and diversity of parechovirus A in a cohort of Malawian children. Arch. Virol. 2019, 164, 799-806. [CrossRef] [PubMed]

34. Faria, N.R.; de Vries, M.; van Hemert, F.J.; Benschop, K.; van der Hoek, L. Rooting human parechovirus evolution in time. BMC Evol. Biol. 2009, 9, 164. [CrossRef] [PubMed]

35. Benschop, K.S.; Williams, C.H.; Wolthers, K.C.; Stanway, G.; Simmonds, P. Widespread recombination within human parechoviruses: Analysis of temporal dynamics and constraints. J. Gen. Virol. 2008, 89, 1030-1035. [CrossRef] [PubMed]

36. Benschop, K.S.; de Vries, M.; Minnaar, R.P.; Stanway, G.; van der Hoek, L.; Wolthers, K.C.; Simmonds, P. Comprehensive full-length sequence analyses of human parechoviruses: Diversity and recombination. J. Gen. Virol. 2010, 91, 145-154. [CrossRef] [PubMed]

37. Simmonds, P.; Welch, J. Frequency and dynamics of recombination within different species of human enteroviruses. J. Virol. 2006, 80, 483-493. [CrossRef] [PubMed]

38. Van der Sanden, S.M.; Koopmans, M.P.; van der Avoort, H.G. Detection of human enteroviruses and parechoviruses as part of the national enterovirus surveillance in the Netherlands, 1996-2011. Eur. J. Clin. Microbiol. Infect. Dis. 2013, 32, 1525-1531. [CrossRef]

39. Khetsuriani, N.; Lamonte, A.; Oberste, M.S.; Pallansch, M. Neonatal enterovirus infections reported to the national enterovirus surveillance system in the United States, 1983-2003. Pediatr. Infect. Dis. J. 2006, 25, 889-893. [CrossRef]

40. Khetsuriani, N.; Lamonte-Fowlkes, A.; Oberst, S.; Pallansch, M.A.; Centers for Disease Control and Prevention. Enterovirus surveillance-United States, 1970-2005. MMWR Surveill. Summ. 2006, 55, 1-20.

41. Van der Sanden, S.; de Bruin, E.; Vennema, H.; Swanink, C.; Koopmans, M.; van der Avoort, H. Prevalence of human parechovirus in the Netherlands in 2000 to 2007. J. Clin. Microbiol. 2008, 46, 2884-2889. [CrossRef]

42. Janes, V.A.; Minnaar, R.; Koen, G.; van Eijk, H.; Dijkman-de Haan, K.; Pajkrt, D.; Wolthers, K.C.; Benschop, K.S. Presence of human non-polio enterovirus and parechovirus genotypes in an Amsterdam hospital in 2007 to 2011 compared to national and international published surveillance data: A comprehensive review. Euro Surveill. 2014, 19. [CrossRef] [PubMed]

43. Abedi, G.R.; Watson, J.T.; Nix, W.A.; Oberste, M.S.; Gerber, S.I. Enterovirus and Parechovirus Surveillance-United States, 2014-2016. MMWR Morb. Mortal. Wkly. Rep. 2018, 67, 515-518. [CrossRef] [PubMed]

44. Fan, Y.M.; Oikarinen, S.; Lehto, K.M.; Nurminen, N.; Juuti, R.; Mangani, C.; Maleta, K.; Hyoty, H.; Ashorn, P. High prevalence of selected viruses and parasites and their predictors in Malawian children. Epidemiol. Infect. 2019, 147, e90. [CrossRef] [PubMed]

45. Yip, C.C.; Lo, K.L.; Que, T.L.; Lee, R.A.; Chan, K.H.; Yuen, K.Y.; Woo, P.C.; Lau, S.K. Epidemiology of human parechovirus, Aichi virus and salivirus in fecal samples from hospitalized children with gastroenteritis in Hong Kong. Virol. J. 2014, 11, 182. [CrossRef] [PubMed]

46. Bubba, L.; Martinelli, M.; Pellegrinelli, L.; Primache, V.; Tanzi, E.; Pariani, E.; Binda, S. A 4-year Study on Epidemiologic and Molecular Characteristics of Human Parechoviruses and Enteroviruses Circulating in Children Younger Than 5 Years in Northern Italy. Pediatr. Infect. Dis. J. 2017, 36, 13-19. [CrossRef] [PubMed]

47. Zhong, H.; Lin, Y.; Sun, J.; Su, L.; Cao, L.; Yang, Y.; Xu, J. Prevalence and genotypes of human parechovirus in stool samples from hospitalized children in Shanghai, China, 2008 and 2009. J. Med. Virol. 2011, 83, 1428-1434. [CrossRef] [PubMed] 
48. Alam, M.M.; Khurshid, A.; Shaukat, S.; Rana, M.S.; Sharif, S.; Angez, M.; Nisar, N.; Aamir, U.B.; Naeem, M.; Zaidi, S.S. Viral etiologies of acute dehydrating gastroenteritis in pakistani children: Confounding role of parechoviruses. Viruses 2015, 7, 378-393. [CrossRef]

49. Patil, P.R.; Ganorkar, N.N.; Gopalkrishna, V. Epidemiology and genetic diversity of human parechoviruses circulating among children hospitalised with acute gastroenteritis in Pune, Western India: A 5-years study. Epidemiol. Infect. 2018, 146, 11-18. [CrossRef]

50. Alam, M.M.; Khurshid, A.; Shaukat, S.; Rana, M.S.; Sharif, S.; Angez, M.; Nisar, N.; Naeem, M.; Zahoor Zaidi, S.S. Human parechovirus genotypes $-10,-13$ and -15 in Pakistani children with acute dehydrating gastroenteritis. PLoS ONE 2013, 8, e78377. [CrossRef]

51. Kolehmainen, P.; Siponen, A.; Smura, T.; Kallio-Kokko, H.; Vapalahti, O.; Jaaskelainen, A.; Tauriainen, S. Intertypic recombination of human parechovirus 4 isolated from infants with sepsis-like disease. J. Clin. Virol. 2017, 88, 1-7. [CrossRef]

52. Ohba, K.; Leow, M.K.; Singh, B.K.; Sinha, R.A.; Lesmana, R.; Liao, X.H.; Ghosh, S.; Refetoff, S.; Sng, J.C.; Yen, P.M. Desensitization and Incomplete Recovery of Hepatic Target Genes After Chronic Thyroid Hormone Treatment and Withdrawal in Male Adult Mice. Endocrinology 2016, 157, 1660-1672. [CrossRef] [PubMed]

53. Fischer, T.K.; Midgley, S.; Dalgaard, C.; Nielsen, A.Y. Human parechovirus infection, Denmark. Emerg. Infect. Dis. 2014, 20, 83-87. [CrossRef] [PubMed]

54. Selvarangan, R.; Nzabi, M.; Selvaraju, S.B.; Ketter, P.; Carpenter, C.; Harrison, C.J. Human parechovirus 3 causing sepsis-like illness in children from midwestern United States. Pediatr. Infect. Dis. J. 2011, 30, $238-242$. [CrossRef] [PubMed]

55. Harvala, H.; McLeish, N.; Kondracka, J.; McIntyre, C.L.; McWilliam Leitch, E.C.; Templeton, K.; Simmonds, P. Comparison of human parechovirus and enterovirus detection frequencies in cerebrospinal fluid samples collected over a 5-year period in edinburgh: HPeV type 3 identified as the most common picornavirus type. J. Med. Virol. 2011, 83, 889-896. [CrossRef]

56. Harvala, H.; Calvert, J.; Van Nguyen, D.; Clasper, L.; Gadsby, N.; Molyneaux, P.; Templeton, K.; McWilliams Leitch, C.; Simmonds, P. Comparison of diagnostic clinical samples and environmental sampling for enterovirus and parechovirus surveillance in Scotland, 2010 to 2012. Euro Surveill. 2014, 19. [CrossRef]

57. Joki-Korpela, P.; Roivainen, M.; Lankinen, H.; Poyry, T.; Hyypia, T. Antigenic properties of human parechovirus 1. J. Gen. Virol. 2000, 81, 1709-1718. [CrossRef]

58. Tauriainen, S.; Martiskainen, M.; Oikarinen, S.; Lonnrot, M.; Viskari, H.; Ilonen, J.; Simell, O.; Knip, M.; Hyoty, H. Human parechovirus 1 infections in young children-No association with type 1 diabetes. J. Med. Virol. 2007, 79, 457-462. [CrossRef]

59. Westerhuis, B.; Kolehmainen, P.; Benschop, K.; Nurminen, N.; Koen, G.; Koskiniemi, M.; Simell, O.; Knip, M.; Hyoty, H.; Wolthers, K.; et al. Human parechovirus seroprevalence in Finland and the Netherlands. J. Clin. Virol. 2013, 58, 211-215. [CrossRef]

60. Tanaka, S.; Aoki, Y.; Matoba, Y.; Yahagi, K.; Itagaki, T.; Matsuzaki, Y.; Mizuta, K. Seroepidemiology of human parechovirus types 1, 3, and 6 in Yamagata, Japan, in 2014. Microbiol. Immunol. 2016, 60, 854-858. [CrossRef]

61. Watanabe, K.; Hirokawa, C.; Tazawa, T. Seropositivity and epidemiology of human parechovirus types 1, 3, and 6 in Japan. Epidemiol. Infect. 2016, 144, 3451-3460. [CrossRef]

62. Westerhuis, B.M.; Benschop, K.S.; Koen, G.; Claassen, Y.B.; Wagner, K.; Bakker, A.Q.; Wolthers, K.C.; Beaumont, T. Human Memory B Cells Producing Potent Cross-Neutralizing Antibodies against Human Parechovirus: Implications for Prevalence, Treatment, and Diagnosis. J. Virol. 2015, 89, 7457-7464. [CrossRef] [PubMed]

63. Westerhuis, B.M.; Jonker, S.C.; Mattao, S.; Benschop, K.S.; Wolthers, K.C. Growth characteristics of human parechovirus 1 to 6 on different cell lines and cross- neutralization of human parechovirus antibodies: A comparison of the cytopathic effect and real time PCR. Virol. J. 2013, 10, 146. [CrossRef] [PubMed]

64. Baggen, J.; Thibaut, H.J.; Strating, J.; van Kuppeveld, F.J.M. The life cycle of non-polio enteroviruses and how to target it. Nat. Rev. Microbiol. 2018, 16, 368-381. [CrossRef] [PubMed]

65. Jiang, P.; Liu, Y.; Ma, H.C.; Paul, A.V.; Wimmer, E. Picornavirus morphogenesis. Microbiol. Mol. Biol. Rev. 2014, 78, 418-437. [CrossRef]

66. Limpens, R.W.; van der Schaar, H.M.; Kumar, D.; Koster, A.J.; Snijder, E.J.; van Kuppeveld, F.J.; Barcena, M. The transformation of enterovirus replication structures: A three-dimensional study of single- and double-membrane compartments. MBio 2011, 2. [CrossRef] 
67. Krogerus, C.; Egger, D.; Samuilova, O.; Hyypia, T.; Bienz, K. Replication complex of human parechovirus 1. J. Virol. 2003, 77, 8512-8523. [CrossRef]

68. Gazina, E.V.; Mackenzie, J.M.; Gorrell, R.J.; Anderson, D.A. Differential requirements for COPI coats in formation of replication complexes among three genera of Picornaviridae. J. Virol. 2002, 76, 11113-11122. [CrossRef]

69. Schultheiss, T.; Emerson, S.U.; Purcell, R.H.; Gauss-Muller, V. Polyprotein processing in echovirus 22: A first assessment. Biochem. Biophys. Res. Commun. 1995, 217, 1120-1127. [CrossRef]

70. Feng, Z.; Hensley, L.; McKnight, K.L.; Hu, F.; Madden, V.; Ping, L.; Jeong, S.H.; Walker, C.; Lanford, R.E.; Lemon, S.M. A pathogenic picornavirus acquires an envelope by hijacking cellular membranes. Nature 2013, 496, 367-371. [CrossRef]

71. Bird, S.W.; Maynard, N.D.; Covert, M.W.; Kirkegaard, K. Nonlytic viral spread enhanced by autophagy components. Proc. Natl. Acad. Sci. USA 2014, 111, 13081-13086. [CrossRef]

72. Robinson, S.M.; Tsueng, G.; Sin, J.; Mangale, V.; Rahawi, S.; McIntyre, L.L.; Williams, W.; Kha, N.; Cruz, C.; Hancock, B.M.; et al. Coxsackievirus B exits the host cell in shed microvesicles displaying autophagosomal markers. PLoS Pathog. 2014, 10, e1004045. [CrossRef] [PubMed]

73. Too, I.H.; Yeo, H.; Sessions, O.M.; Yan, B.; Libau, E.A.; Howe, J.L.; Lim, Z.Q.; Suku-Maran, S.; Ong, W.Y.; Chua, K.B.; et al. Enterovirus 71 infection of motor neuron-like NSC-34 cells undergoes a non-lytic exit pathway. Sci. Rep. 2016, 6, 36983. [CrossRef] [PubMed]

74. Chen, Y.H.; Du, W.; Hagemeijer, M.C.; Takvorian, P.M.; Pau, C.; Cali, A.; Brantner, C.A.; Stempinski, E.S.; Connelly, P.S.; Ma, H.C.; et al. Phosphatidylserine vesicles enable efficient en bloc transmission of enteroviruses. Cell 2015, 160, 619-630. [CrossRef] [PubMed]

75. Plow, E.F.; Haas, T.A.; Zhang, L.; Loftus, J.; Smith, J.W. Ligand binding to integrins. J. Biol. Chem. 2000, 275, 21785-21788. [CrossRef]

76. Roivainen, M.; Piirainen, L.; Hovi, T.; Virtanen, I.; Riikonen, T.; Heino, J.; Hyypia, T. Entry of coxsackievirus A9 into host cells: Specific interactions with alpha v beta 3 integrin, the vitronectin receptor. Virology 1994, 203, 357-365. [CrossRef]

77. Bergelson, J.M.; Shepley, M.P.; Chan, B.M.; Hemler, M.E.; Finberg, R.W. Identification of the integrin VLA-2 as a receptor for echovirus 1. Science 1992, 255, 1718-1720. [CrossRef]

78. Neff, S.; Sa-Carvalho, D.; Rieder, E.; Mason, P.W.; Blystone, S.D.; Brown, E.J.; Baxt, B. Foot-and-mouth disease virus virulent for cattle utilizes the integrin alpha(v)beta3 as its receptor. J. Virol. 1998, 72, 3587-3594.

79. Boonyakiat, Y.; Hughes, P.J.; Ghazi, F.; Stanway, G. Arginine-glycine-aspartic acid motif is critical for human parechovirus 1 entry. J. Virol. 2001, 75, 10000-10004. [CrossRef]

80. Joki-Korpela, P.; Marjomaki, V.; Krogerus, C.; Heino, J.; Hyypia, T. Entry of human parechovirus 1. J. Virol. 2001, 75, 1958-1967. [CrossRef]

81. Triantafilou, K.; Triantafilou, M.; Takada, Y.; Fernandez, N. Human parechovirus 1 utilizes integrins alphavbeta3 and alphavbeta1 as receptors. J. Virol. 2000, 74, 5856-5862. [CrossRef]

82. Merilahti, P.; Tauriainen, S.; Susi, P. Human Parechovirus 1 Infection Occurs via alphaVbeta1 Integrin. PLoS ONE 2016, 11, e0154769. [CrossRef] [PubMed]

83. Karelehto, E.; Cristella, C.; Yu, X.; Sridhar, A.; Hulsdouw, R.; de Haan, K.; van Eijk, H.; Koekkoek, S.; Pajkrt, D.; de Jong, M.D.; et al. Polarized Entry of Human Parechoviruses in the Airway Epithelium. Front. Cell. Infect. Microbiol. 2018, 8, 294. [CrossRef] [PubMed]

84. Harvala, H.; Wolthers, K.C.; Simmonds, P. Parechoviruses in children: Understanding a new infection. Curr. Opin. Infect. Dis. 2010, 23, 224-230. [CrossRef] [PubMed]

85. King, S.L.; Kamata, T.; Cunningham, J.A.; Emsley, J.; Liddington, R.C.; Takada, Y.; Bergelson, J.M. Echovirus 1 interaction with the human very late antigen-2 (integrin alpha2beta1) I domain. Identification of two independent virus contact sites distinct from the metal ion-dependent adhesion site. J. Biol. Chem. 1997, 272, 28518-28522. [CrossRef] [PubMed]

86. Ylipaasto, P.; Eskelinen, M.; Salmela, K.; Hovi, T.; Roivainen, M. Vitronectin receptors, alpha v integrins, are recognized by several non-RGD-containing echoviruses in a continuous laboratory cell line and also in primary human Langerhans' islets and endothelial cells. J. Gen. Virol. 2010, 91, 155-165. [CrossRef] [PubMed] 
87. Heikkila, O.; Merilahti, P.; Hakanen, M.; Karelehto, E.; Alanko, J.; Sukki, M.; Kiljunen, S.; Susi, P. Integrins are not essential for entry of coxsackievirus A9 into SW480 human colon adenocarcinoma cells. Virol. J. 2016, 13, 171. [CrossRef]

88. Merilahti, P.; Karelehto, E.; Susi, P. Role of Heparan Sulfate in Cellular Infection of Integrin-Binding Coxsackievirus A9 and Human Parechovirus 1 Isolates. PLoS ONE 2016, 11, e0147168. [CrossRef]

89. Ward, T.; Powell, R.M.; Pipkin, P.A.; Evans, D.J.; Minor, P.D.; Almond, J.W. Role for beta2-microglobulin in echovirus infection of rhabdomyosarcoma cells. J. Virol. 1998, 72, 5360-5365.

90. Triantafilou, M.; Triantafilou, K.; Wilson, K.M.; Takada, Y.; Fernandez, N.; Stanway, G. Involvement of beta2-microglobulin and integrin alphavbeta3 molecules in the coxsackievirus A9 infectious cycle. J. Gen. Virol. 1999, 80 Pt 10, 2591-2600. [CrossRef]

91. Morosky, S.; Wells, A.I.; Lemon, K.; Evans, A.S.; Schamus, S.; Bakkenist, C.J.; Coyne, C.B. The neonatal Fc receptor is a pan-echovirus receptor. Proc. Natl. Acad. Sci. USA 2019, 116, 3758-3763. [CrossRef]

92. Benschop, K.; Minnaar, R.; Koen, G.; van Eijk, H.; Dijkman, K.; Westerhuis, B.; Molenkamp, R.; Wolthers, K. Detection of human enterovirus and human parechovirus ( $\mathrm{HPeV}$ ) genotypes from clinical stool samples: Polymerase chain reaction and direct molecular typing, culture characteristics, and serotyping. Diagn. Microbiol. Infect. Dis. 2010, 68, 166-173. [CrossRef] [PubMed]

93. Izumita, R.; Deuchi, K.; Aizawa, Y.; Habuka, R.; Watanabe, K.; Otsuka, T.; Saitoh, A. Intrafamilial Transmission of Parechovirus A and Enteroviruses in Neonates and Young Infants. J. Pediatr. Infect Dis. Soc. 2018. [CrossRef] [PubMed]

94. Aizawa, Y.; Yamanaka, T.; Watanabe, K.; Oishi, T.; Saitoh, A. Asymptomatic children might transmit human parechovirus type 3 to neonates and young infants. J. Clin. Virol. 2015, 70, 105-108. [CrossRef] [PubMed]

95. Wildenbeest, J.G.; Benschop, K.S.; Minnaar, R.P.; Bouma-de Jongh, S.; Wolthers, K.C.; Pajkrt, D. Clinical relevance of positive human parechovirus type 1 and 3 PCR in stool samples. Clin. Microbiol. Infect. 2014, 20, O640-O647. [CrossRef] [PubMed]

96. Khatami, A.; McMullan, B.J.; Webber, M.; Stewart, P.; Francis, S.; Timmers, K.J.; Rodas, E.; Druce, J.; Mehta, B.; Sloggett, N.A.; et al. Sepsis-like disease in infants due to human parechovirus type 3 during an outbreak in Australia. Clin. Infect. Dis. 2015, 60, 228-236. [CrossRef]

97. McNeale, D.; Wang, C.Y.T.; Arden, K.E.; Mackay, I.M. HPeV-3 predominated among Parechovirus A positive infants during an outbreak in 2013-2014 in Queensland, Australia. J. Clin. Virol. 2018, 98, 28-32. [CrossRef]

98. Midgley, C.M.; Jackson, M.A.; Selvarangan, R.; Franklin, P.; Holzschuh, E.L.; Lloyd, J.; Scaletta, J.; Straily, A.; Tubach, S.; Willingham, A.; et al. Severe Parechovirus 3 Infections in Young Infants-Kansas and Missouri, 2014. J. Pediatr. Infect. Dis. Soc. 2018, 7, 104-112. [CrossRef]

99. Strenger, V.; Diedrich, S.; Boettcher, S.; Richter, S.; Maritschnegg, P.; Gangl, D.; Fuchs, S.; Grangl, G.; Resch, B.; Urlesberger, B. Nosocomial Outbreak of Parechovirus 3 Infection among Newborns, Austria, 2014. Emerg. Infect. Dis. 2016, 22, 1631-1634. [CrossRef]

100. Yamamoto, M.; Abe, K.; Kuniyori, K.; Kunii, E.; Ito, F.; Kasama, Y.; Yoshioka, Y.; Noda, M. Epidemic of human parechovirus type 3 in Hiroshima city, Japan in 2008. Jpn. J. Infect. Dis. 2009, 62, 244-245.

101. Verboon-Maciolek, M.A.; Groenendaal, F.; Hahn, C.D.; Hellmann, J.; van Loon, A.M.; Boivin, G.; de Vries, L.S. Human parechovirus causes encephalitis with white matter injury in neonates. Ann. Neurol. 2008, 64, 266-273. [CrossRef]

102. Britton, P.N.; Khandaker, G.; Khatami, A.; Teutsch, S.; Francis, S.; McMullan, B.J.; Jones, C.A. High prevalence of developmental concern amongst infants at 12 months following hospitalised parechovirus infection. J. Paediatr. Child. Health 2018, 54, 289-295. [CrossRef] [PubMed]

103. Berk, M.C.; Bruning, A.H.L.; van Wassenaer-Leemhuis, A.G.; Wolthers, K.C.; Pajkrt, D. Human Parechovirus Meningitis with Adverse Neurodevelopmental Outcome: A Case Report. Pediatr. Infect. Dis. J. 2018, 37, e256-e257. [CrossRef] [PubMed]

104. Britton, P.N.; Dale, R.C.; Nissen, M.D.; Crawford, N.; Elliott, E.; Macartney, K.; Khandaker, G.; Booy, R.; Jones, C.A.; Investigators, P.-A. Parechovirus Encephalitis and Neurodevelopmental Outcomes. Pediatrics 2016, 137, e20152848. [CrossRef] [PubMed]

105. Ferreras Antolin, L.; Kadambari, S.; Braccio, S.; Tang, J.W.; Xerry, J.; Allen, D.J.; Ladhani, S.N.; Parechovirus Surveillance, N. Increased detection of human parechovirus infection in infants in England during 2016: Epidemiology and clinical characteristics. Arch. Dis. Child. 2018, 103, 1061-1066. [CrossRef] [PubMed] 
106. Black, S.; Bradley, C.; Lai, F.Y.; Shenoy, S.; Bandi, S.; Allen, D.J.; Tang, J.W. Comparing the Clinical Severity of Disease Caused by Enteroviruses and Human Parechoviruses in Neonates and Infants. Pediatr. Infect. Dis. J. 2019, 38, e36-e38. [CrossRef] [PubMed]

107. Kadambari, S.; Braccio, S.; Ribeiro, S.; Allen, D.J.; Pebody, R.; Brown, D.; Cunney, R.; Sharland, M.; Ladhani, S. Enterovirus and parechovirus meningitis in infants younger than 90 days old in the UK and Republic of Ireland: A British Paediatric Surveillance Unit study. Arch. Dis. Child. 2019, 104, 552-557. [CrossRef]

108. Renna, S.; Bergamino, L.; Pirlo, D.; Rossi, A.; Furione, M.; Piralla, A.; Mascaretti, M.; Cristina, E.; Marazzi, M.G.; Di Pietro, P. A case of neonatal human parechovirus encephalitis with a favourable outcome. Brain Dev. 2014, 36, 70-73. [CrossRef]

109. Mizuta, K.; Kuroda, M.; Kurimura, M.; Yahata, Y.; Sekizuka, T.; Aoki, Y.; Ikeda, T.; Abiko, C.; Noda, M.; Kimura, H.; et al. Epidemic myalgia in adults associated with human parechovirus type 3 infection, Yamagata, Japan, 2008. Emerg. Infect. Dis. 2012, 18, 1787-1793. [CrossRef]

110. Mizuta, K.; Yamakawa, T.; Nagasawa, H.; Itagaki, T.; Katsushima, F.; Katsushima, Y.; Shimizu, Y.; Ito, S.; Aoki, Y.; Ikeda, T.; et al. Epidemic myalgia associated with human parechovirus type 3 infection among adults occurs during an outbreak among children: Findings from Yamagata, Japan, in 2011. J. Clin. Virol. 2013, 58, 188-193. [CrossRef]

111. Kong, K.L.; Lau, J.S.Y.; Goh, S.M.; Wilson, H.L.; Catton, M.; Korman, T.M. Myocarditis Caused by Human Parechovirus in Adult. Emerg. Infect. Dis. 2017, 23, 1571-1573. [CrossRef]

112. Shinomoto, M.; Kawasaki, T.; Sugahara, T.; Nakata, K.; Kotani, T.; Yoshitake, H.; Yuasa, K.; Saeki, M.; Fujiwara, Y. First report of human parechovirus type 3 infection in a pregnant woman. Int. J. Infect. Dis. 2017, 59, 22-24. [CrossRef] [PubMed]

113. Han, T.H.; Kim, C.H.; Park, S.H.; Chung, J.Y.; Hwang, E.S. Detection of human parechoviruses in children with gastroenteritis in South Korea. Arch. Virol. 2011, 156, 1471-1475. [CrossRef] [PubMed]

114. Pham, N.T.; Takanashi, S.; Tran, D.N.; Trinh, Q.D.; Abeysekera, C.; Abeygunawardene, A.; Khamrin, P.; Okitsu, S.; Shimizu, H.; Mizuguchi, M.; et al. Human parechovirus infection in children hospitalized with acute gastroenteritis in Sri Lanka. J. Clin. Microbiol. 2011, 49, 364-366. [CrossRef] [PubMed]

115. Vollbach, S.; Muller, A.; Drexler, J.F.; Simon, A.; Drosten, C.; Eis-Hubinger, A.M.; Panning, M. Prevalence, type and concentration of human enterovirus and parechovirus in cerebrospinal fluid samples of pediatric patients over a 10-year period: A retrospective study. Virol. J. 2015, 12, 199. [CrossRef]

116. Pellegrinelli, L.; Bubba, L.; Galli, C.; Anselmi, G.; Primache, V.; Binda, S.; Pariani, E. Epidemiology and molecular characterization of influenza viruses, human parechoviruses and enteroviruses in children up to 5 years with influenza-like illness in Northern Italy during seven consecutive winter seasons (2010-2017). J. Gen. Virol. 2017, 98, 2699-2711. [CrossRef] [PubMed]

117. Mladenova, Z.; Dikova, A.; Thongprachum, A.; Petrov, P.; Pekova, L.; Komitova, R.; Iturriza-Gomara, M.; Ushijima, H. Diversity of human parechoviruses in Bulgaria, 2011: Detection of rare genotypes 8 and 10. Infect. Genet. Evol. 2015, 36, 315-322. [CrossRef]

118. Harvala, H.; Robertson, I.; Chieochansin, T.; McWilliam Leitch, E.C.; Templeton, K.; Simmonds, P. Specific association of human parechovirus type 3 with sepsis and fever in young infants, as identified by direct typing of cerebrospinal fluid samples. J. Infect. Dis. 2009, 199, 1753-1760. [CrossRef]

119. Harvala, H.; Robertson, I.; McWilliam Leitch, E.C.; Benschop, K.; Wolthers, K.C.; Templeton, K.; Simmonds, P. Epidemiology and clinical associations of human parechovirus respiratory infections. J. Clin. Microbiol. 2008, 46, 3446-3453. [CrossRef]

120. Benschop, K.; Molenkamp, R.; van der Ham, A.; Wolthers, K.; Beld, M. Rapid detection of human parechoviruses in clinical samples by real-time PCR. J. Clin. Virol. 2008, 41, 69-74. [CrossRef]

121. Seth, R.B.; Sun, L.; Chen, Z.J. Antiviral innate immunity pathways. Cell Res. 2006, 16, 141-147. [CrossRef]

122. Triantafilou, K.; Vakakis, E.; Orthopoulos, G.; Ahmed, M.A.; Schumann, C.; Lepper, P.M.; Triantafilou, M. TLR8 and TLR7 are involved in the host's immune response to human parechovirus 1. Eur. J. Immunol. 2005, 35, 2416-2423. [CrossRef] [PubMed]

123. Chang, J.T.; Yang, C.S.; Chen, Y.S.; Chen, B.C.; Chiang, A.J.; Chang, Y.H.; Tsai, W.L.; Lin, Y.S.; Chao, D.; Chang, T.H. Genome and infection characteristics of human parechovirus type 1: The interplay between viral infection and type I interferon antiviral system. PLoS ONE 2015, 10, e0116158. [CrossRef] [PubMed] 
124. Lin, T.H.; Cheng, C.C.; Su, H.H.; Huang, N.C.; Chen, J.J.; Kang, H.Y.; Chang, T.H. Lipopolysaccharide Attenuates Induction of Proallergic Cytokines, Thymic Stromal Lymphopoietin, and Interleukin 33 in Respiratory Epithelial Cells Stimulated with PolyI:C and Human Parechovirus. Front. Immunol. 2016, 7, 440. [CrossRef] [PubMed]

125. Alho, A.; Marttila, J.; Ilonen, J.; Hyypia, T. Diagnostic potential of parechovirus capsid proteins. J. Clin. Microbiol. 2003, 41, 2294-2299. [CrossRef]

126. Van de Ven, A.A.; Douma, J.W.; Rademaker, C.; van Loon, A.M.; Wensing, A.M.; Boelens, J.J.; Sanders, E.A.; van Montfrans, J.M. Pleconaril-resistant chronic parechovirus-associated enteropathy in agammaglobulinaemia. Antivir. Ther. 2011, 16, 611-614. [CrossRef]

127. Wildenbeest, J.G.; Wolthers, K.C.; Straver, B.; Pajkrt, D. Successful IVIG treatment of human parechovirus-associated dilated cardiomyopathy in an infant. Pediatrics 2013, 132, e243-e247. [CrossRef]

128. Shakeel, S.; Westerhuis, B.M.; Ora, A.; Koen, G.; Bakker, A.Q.; Claassen, Y.; Wagner, K.; Beaumont, T.; Wolthers, K.C.; Butcher, S.J. Structural Basis of Human Parechovirus Neutralization by Human Monoclonal Antibodies. J. Virol. 2015, 89, 9571-9580. [CrossRef]

129. Aizawa, Y.; Watanabe, K.; Oishi, T.; Hirano, H.; Hasegawa, I.; Saitoh, A. Role of Maternal Antibodies in Infants with Severe Diseases Related to Human Parechovirus Type 3. Emerg. Infect. Dis. 2015, 21, 1966-1972. [CrossRef]

130. Karelehto, E.; Wildenbeest, J.G.; Benschop, K.S.M.; Koen, G.; Rebers, S.; Bouma-de Jongh, S.; Westerhuis, B.M.; de Jong, M.D.; Pajkrt, D.; Wolthers, K.C. Human Parechovirus 1, 3 and 4 Neutralizing Antibodies in Dutch Mothers and Infants and Their Role in Protection Against Disease. Pediatr. Infect. Dis. J. 2018, 37, 1304-1308. [CrossRef]

131. Calvert, J.; Chieochansin, T.; Benschop, K.S.; McWilliam Leitch, E.C.; Drexler, J.F.; Grywna, K.; da Costa Ribeiro, H., Jr.; Drosten, C.; Harvala, H.; Poovorawan, Y.; et al. Recombination dynamics of human parechoviruses: Investigation of type-specific differences in frequency and epidemiological correlates. J. Gen. Virol. 2010, 91, 1229-1238. [CrossRef]

132. Lin, T.Y.; Chang, L.Y.; Huang, Y.C.; Hsu, K.H.; Chiu, C.H.; Yang, K.D. Different proinflammatory reactions in fatal and non-fatal enterovirus 71 infections: Implications for early recognition and therapy. Acta Paediatr. 2002, 91, 632-635. [CrossRef] [PubMed]

133. Wang, S.M.; Lei, H.Y.; Huang, K.J.; Wu, J.M.; Wang, J.R.; Yu, C.K.; Su, I.J.; Liu, C.C. Pathogenesis of enterovirus 71 brainstem encephalitis in pediatric patients: Roles of cytokines and cellular immune activation in patients with pulmonary edema. J. Infect. Dis. 2003, 188, 564-570. [CrossRef] [PubMed]

134. Lin, T.Y.; Hsia, S.H.; Huang, Y.C.; Wu, C.T.; Chang, L.Y. Proinflammatory cytokine reactions in enterovirus 71 infections of the central nervous system. Clin. Infect. Dis. 2003, 36, 269-274. [CrossRef] [PubMed]

135. Guo, X.J.; Thomas, P.G. New fronts emerge in the influenza cytokine storm. Semin. Immunopathol. 2017, 39, 541-550. [CrossRef]

136. Channappanavar, R.; Perlman, S. Pathogenic human coronavirus infections: Causes and consequences of cytokine storm and immunopathology. Semin. Immunopathol. 2017, 39, 529-539. [CrossRef]

137. Shane, A.L.; Sanchez, P.J.; Stoll, B.J. Neonatal sepsis. Lancet 2017, 390, 1770-1780. [CrossRef]

138. Danielski, L.G.; Giustina, A.D.; Badawy, M.; Barichello, T.; Quevedo, J.; Dal-Pizzol, F.; Petronilho, F. Brain Barrier Breakdown as a Cause and Consequence of Neuroinflammation in Sepsis. Mol. Neurobiol. 2018, 55, 1045-1053. [CrossRef]

139. Barichello, T.; Sayana, P.; Giridharan, V.V.; Arumanayagam, A.S.; Narendran, B.; Della Giustina, A.; Petronilho, F.; Quevedo, J.; Dal-Pizzol, F. Long-Term Cognitive Outcomes After Sepsis: A Translational Systematic Review. Mol. Neurobiol. 2019, 56, 186-251. [CrossRef]

140. Wang, S.M.; Lei, H.Y.; Liu, C.C. Cytokine immunopathogenesis of enterovirus 71 brain stem encephalitis. Clin. Dev. Immunol. 2012, 2012, 876241. [CrossRef]

141. Harvala, H.; Griffiths, M.; Solomon, T.; Simmonds, P. Distinct systemic and central nervous system disease patterns in enterovirus and parechovirus infected children. J. Infect. 2014, 69, 69-74. [CrossRef]

142. Verboon-Maciolek, M.A.; Krediet, T.G.; Gerards, L.J.; de Vries, L.S.; Groenendaal, F.; van Loon, A.M. Severe neonatal parechovirus infection and similarity with enterovirus infection. Pediatr. Infect. Dis. J. 2008, 27, 241-245. [CrossRef] [PubMed] 
143. De Jong, E.P.; van den Beuken, M.G.A.; van Elzakker, E.P.M.; Wolthers, K.C.; Sprij, A.J.; Lopriore, E.; Walther, F.J.; Brus, F. Epidemiology of Sepsis-like Illness in Young Infants: Major Role of Enterovirus and Human Parechovirus. Pediatr. Infect. Dis. J. 2018, 37, 113-118. [CrossRef] [PubMed]

144. Ghanem-Zoubi, N.; Shiner, M.; Shulman, L.M.; Sofer, D.; Wolf, D.; Marva, E.; Kra-Oz, Z.; Shachor-Meyouhas, Y.; Averbuch, D.; Bechor-Fellner, A.; et al. Human parechovirus type 3 central nervous system infections in Israeli infants. J. Clin. Virol. 2013, 58, 205-210. [CrossRef] [PubMed]

145. Sharp, J.; Harrison, C.J.; Puckett, K.; Selvaraju, S.B.; Penaranda, S.; Nix, W.A.; Oberste, M.S.; Selvarangan, R. Characteristics of young infants in whom human parechovirus, enterovirus or neither were detected in cerebrospinal fluid during sepsis evaluations. Pediatr. Infect. Dis. J. 2013, 32, 213-216. [CrossRef]

146. Westerhuis, B.M.; Koen, G.; Wildenbeest, J.G.; Pajkrt, D.; de Jong, M.D.; Benschop, K.S.; Wolthers, K.C. Specific cell tropism and neutralization of human parechovirus types 1 and 3: Implications for pathogenesis and therapy development. J. Gen. Virol. 2012, 93, 2363-2370. [CrossRef]

147. Karelehto, E.; Brouwer, L.; Benschop, K.; Kok, J.; Basile, K.; McMullan, B.; Rawlinson, W.; Druce, J.; Nicholson, S.; Selvarangan, R.; et al. Seroepidemiology of Parechovirus A3 Neutralizing Antibodies, Australia, the Netherlands, and United States. Emerg. Infect. Dis. 2019, 25, 148-152. [CrossRef]

148. Sedmak, G.; Nix, W.A.; Jentzen, J.; Haupt, T.E.; Davis, J.P.; Bhattacharyya, S.; Pallansch, M.A.; Oberste, M.S. Infant deaths associated with human parechovirus infection in Wisconsin. Clin. Infect. Dis. 2010, 50, 357-361. [CrossRef]

149. Van der Linden, L.; Wolthers, K.C.; van Kuppeveld, F.J. Replication and Inhibitors of Enteroviruses and Parechoviruses. Viruses 2015, 7, 4529-4562. [CrossRef]

150. Van der Linden, L.; Ulferts, R.; Nabuurs, S.B.; Kusov, Y.; Liu, H.; George, S.; Lacroix, C.; Goris, N.; Lefebvre, D.; Lanke, K.H.; et al. Application of a cell-based protease assay for testing inhibitors of picornavirus 3C proteases. Antivir. Res. 2014, 103, 17-24. [CrossRef]

151. Tamm, I.; Eggers, H.J. Differences in the selective virus inhibitory action of 2-(alpha-hydroxybenzyl)benzimidazole and guanidine HCl. Virology 1962, 18, 439-447. [CrossRef]

152. Rhoden, E.; Nix, W.A.; Weldon, W.C.; Selvarangan, R. Antifungal azoles itraconazole and posaconazole exhibit potent in vitro antiviral activity against clinical isolates of parechovirus A3 (Picornaviridae). Antivir. Res. 2018, 149, 75-77. [CrossRef] [PubMed]

153. Domanska, A.; Flatt, J.W.; Jukonen, J.J.J.; Geraets, J.A.; Butcher, S.J. A 2.8-Angstrom-Resolution Cryo-Electron Microscopy Structure of Human Parechovirus 3 in Complex with Fab from a Neutralizing Antibody. J. Virol. 2019, 93. [CrossRef] [PubMed]

154. Karelehto, E.; van der Sanden, S.; Geraets, J.A.; Domanska, A.; van der Linden, L.; Hoogendoorn, D.; Koen, G.; van Eijk, H.; Shakeel, S.; Beaumont, T.; et al. Strain-dependent neutralization reveals antigenic variation of human parechovirus 3. Sci. Rep. 2017, 7, 12075. [CrossRef] [PubMed]

155. Sato, T.; Vries, R.G.; Snippert, H.J.; van de Wetering, M.; Barker, N.; Stange, D.E.; van Es, J.H.; Abo, A.; Kujala, P.; Peters, P.J.; et al. Single Lgr5 stem cells build crypt-villus structures in vitro without a mesenchymal niche. Nature 2009, 459, 262-265. [CrossRef] [PubMed]

156. Lancaster, M.A.; Knoblich, J.A. Generation of cerebral organoids from human pluripotent stem cells. Nat. Protoc. 2014, 9, 2329-2340. [CrossRef] [PubMed]

(C) 2019 by the authors. Licensee MDPI, Basel, Switzerland. This article is an open access article distributed under the terms and conditions of the Creative Commons Attribution (CC BY) license (http://creativecommons.org/licenses/by/4.0/). 